\title{
Sugarcane Mosaic: Virus Particles and Relative Resistance of Sugarcane Varieties in Puerto Rico ${ }^{1}$
}

\author{
Lii-Jang $\mathrm{Liu}^{2}$
}

\begin{abstract}
Rod-shaped virus particles were observed under the electron microscope in negatively stained juice obtained from sugarcane mosaic-affected plants of CP31-294. The particles were of strains $A$ and $B$ and measured $720-1,446$ $\mathrm{nm} \times 14-15 \mathrm{~nm}$ and $720-1,730 \mathrm{~nm} \times 14-15 \mathrm{~nm}$, respectively. A total of 51 promising varieties of sugarcane were artificially inoculated with a mixture of mosaic virus strains $A, B$ and $D$ in three separate greenhouse experiments during the last 3 years. PR 1141, PR 1152, PR 62-285, PR 64-1548, PR 65153, PR 65-2538, Q 68 and selection Sóler were found potentially capable of taking mosaic, with an average of $10-19 \%$ infection. However, none of these varieties showed mosaic symptoms in the fields under natural infection. Therefore, they are acceptable for field planting in Puerto Rico.
\end{abstract}

\section{INTRODUCTION}

Mosaic was the most important sugarcane disease in Puerto Rico during 1920-30, when noble cane varieties Cristalina, BH 10(12), and SC $12(4)$ were severely affected. The disease can be found today in restricted areas along the southern coast where B 34-104 and B 37-161 are still planted. Testing prominent selections and varieties for resistance to the disease remains an essential part of the local sugarcane breeding program.

Bruehl in 1953 (1) pioneered in the identification of mosaic virus strains A, B and D in Puerto Rico. Liu in 1972 (7) confirmed the presence of these strains. In addition, he also studied the influence of temperature on symptom expression by sugarcane infected with different strains of the virus under controlled conditions (6). Regardless of strain identification or disease diagnosis, mosaic is traditionally recognized in Puerto Rico by its conspicuous foliage symptoms which consist of islands of normal green on a background of lighter green or yellowish stripes. The virus particles associated with the disease have not been observed previously in Puerto Rico. Information on varietal susceptibility to local strains of the virus is presented in this report.

\footnotetext{
${ }^{1}$ Manuscript submitted to Editorial Board July 21, 1978.

${ }^{2}$ Phytopathologist, Department of Crop Protection, College of Agricultural Science, Agricultural Experiment Station, Mayagüez Campus, University of Puerto Rico, Río Piedras, P.R. The author wishes to express his gratitude to Mr. J. L. Serapión, Mr. G. Ramírez Oliveras, Mr. R. Gandía Caro, Mr. V. Godreau, Assistant Agronomists and Dr. Carlos L. González Molina, Geneticist from the Department of Agronomy of the Agricultural Experiment Station, for their cooperation and supply of sugarcane cuttings for mosaic inoculation trials.
} 


\section{MATERIALS AND MFTHODS}

For electron microscope detection of virus particles associated with the mosaic disease, a slight modification of a negative staining method described by Kitajima (5) was made.

Leaves of sugarcane showing typical mosaic symptoms (strains A and B) as well as those from healthy canes were surface sterilized with $70 \%$ ethanol and then cut into small pieces with a sterile knife. The leaf tissues were chopped vertically on a $3 \times 3$ in plate of dental wax with a sterile razor blade in a sterile petri dish containing $100 \mathrm{ml}$ of redistilled water. The suspension was then poured into a test tube. A drop of $0.5 \%$ sucrose solution was added to the suspension on a 1:1 basis. The suspension was stained with a $1.5 \%$ solution of phosphotungstic acid (PTA). A carbon coated grid was left floating on the surface of the suspension for approximately 10 to $15 \mathrm{~min}$. The excess water on the grid was removed carefully with a piece of filter paper and the grid was examined immediately in a Siemens electron microscope at $80 \mathrm{KV}$.

In connection with the testing of sugarcane varieties for mosaic resistance, three separate greenhouse inoculation trials were carried out. For the first experiment, plants were inoculated on April 25, 1975, and symptoms recorded on June 25, 1975 (average air temperature of $77.2^{\circ}$ F). For the second experiment, plants were inoculated on March 2, 1976, and symptoms recorded on May 2, 1976 (average air temperature of $78.8^{\circ}$ F). For the third experiment, plants were inoculated on March 3, 1978, and symptoms recorded on April 11, 1978 (average air temperature of $\left.75.1^{\circ} \mathrm{F}\right)$.

For the first trial, a total of 37 varieites were inoculated: B 34-104, PR 1140, PR 1141, PR 1148, PR 1152, PR 1249, PR 61-64, PR 61-632, PR 61-902, PR 62-66, PR 62-195, PR 62-285, PR 62-469, PR 62-626, PR 62739, PR 63-227, PR 63-437, PR 63-525, PR 64-15, PR 64-245, PR 64352, PR 64-610, PR 64-747, PR 64-1618, PR 64-1791, PR 64-2002, PR 64-2705, PR 65-109, PR 65-153, PR 65-199, PR 65-339, PR 65-413, PR 65-625, PR 65-2638, Q 68, Sóller and NCo 310. These sugarcanes were inoculated with juice pressed from leaves of variety CP 31-294 showing symptoms of mosaic incited by virus strains A, B and D. Seín's technique of inoculation (9) was used. The test was replicated 3 to 5 times depending upon the availability of seeds. More than 100 single-eyed seedpieces were planted. The number of plants inoculated varied from 38 to 106 for each of the 37 varieties. The commercially known mosaic susceptible variety, B 34-104, was included as a control.

For the second trial, a total of 20 varieties (B 34-104, PR 980, PR 1140, PR 1141, PR 1152, PR 1248, PR 1249, PR 62-285, PR 63-192, PR 63-227, PR 63-488, PR 63-1165, PR 64-352, PR 64-1128, PR 64-1548, PR 641628, PR 64-1791, PR 65-153, PR 65-292, and selection Sóller) were 
inoculated with juice extracted from sugarcane leaves affected by mosaic virus strain A, B and D. Sein's (9) technique of inoculation was used. The test was replicated four times, except with one variety, PR 63-192, because of the unavailability of seedpieces. More than 100 singled-eyed cuttings per variety were planted. Both the commercially known mosaic susceptible variety B 34-104 and the mosaic resistant variety PR 980 were included as controls. Data on the number of plants that developed mosaic symptoms were recorded and statistically analyzed 2 mo after inoculation.

For the third trial, a total of 18 varieties were tested: B 34-104, PR 980, PR 1124, PR 1148, PR-61-632, PR 62-469, PR 62-739, PR 63-488, PR 63-525, PR 63-1165, PR 64-1548, PR 65-625, PR 65-1128, PR 65-2538, PR 67-245, PR 67-1070, PR 67-3129, and PR 69-2030. Matz's technique (8) was used. The test was replicated four times. More than 100 singleeyed seed-pieces per variety were planted. As in the case of the second trial, both the commercially known mosaic susceptible variety B 34-104 and the resistant variety PR 980 were included as controls. Data on the number of plants that developed mosaic symptoms were recorded and statistically analyzed approximately 5 weeks after inoculation.

\section{RESULTS}

\section{ELECTRON MICROSCOPE STUDIES}

As shown in figures 1 and 2, bunches of rod-shaped virus particles, measuring 720-1,446 nm $\times 14-15 \mathrm{~nm}$ and $720-1,730 \mathrm{~nm} \times 14-15 \mathrm{~nm}$ were observed under the electron microscope in the negatively stained sugarcane juice pressed from variety CP 31-294. These same particles were not found in the healthy juice. The frequency of distribution of the lengths of the virus particles is presented in figure 3.

\section{VARIETY MOSAIC INOCULATION TRIALS}

\section{Trial number 1}

As shown in table 1, the results obtained from trial No. 1 indicated that the majority of the varieties tested (20 out of 37 ) were either highly resistant or immune to the mosaic virus. The following varieties belong to this group: PR 1148, PR 61-64, PR 61-632, PR 61-902, PR 62-66, PR 62-195, PR 62-469, PR 62-626, PR 63-437, PR 63-525, PR 65-15, PR 64610, PR 64-747, PR 64-618, PR 64-1791, PR 64-2705, PR 65-109, PR 65199, PR 65-339, and PR 65-2368. However, varieties such as PR 1140, PR 1141, PR 1152, PR 1249, PR 62-285, PR 62-739, PR 63-227, PR 64245, PR 64-352, PR 64-2002, PR 65-153, PR 65-413, PR 65-625, Q 68, and selection Sóller did not differ significantly in percentage of infection by mosaic virus from the commercially susceptible variety B 34-104. 


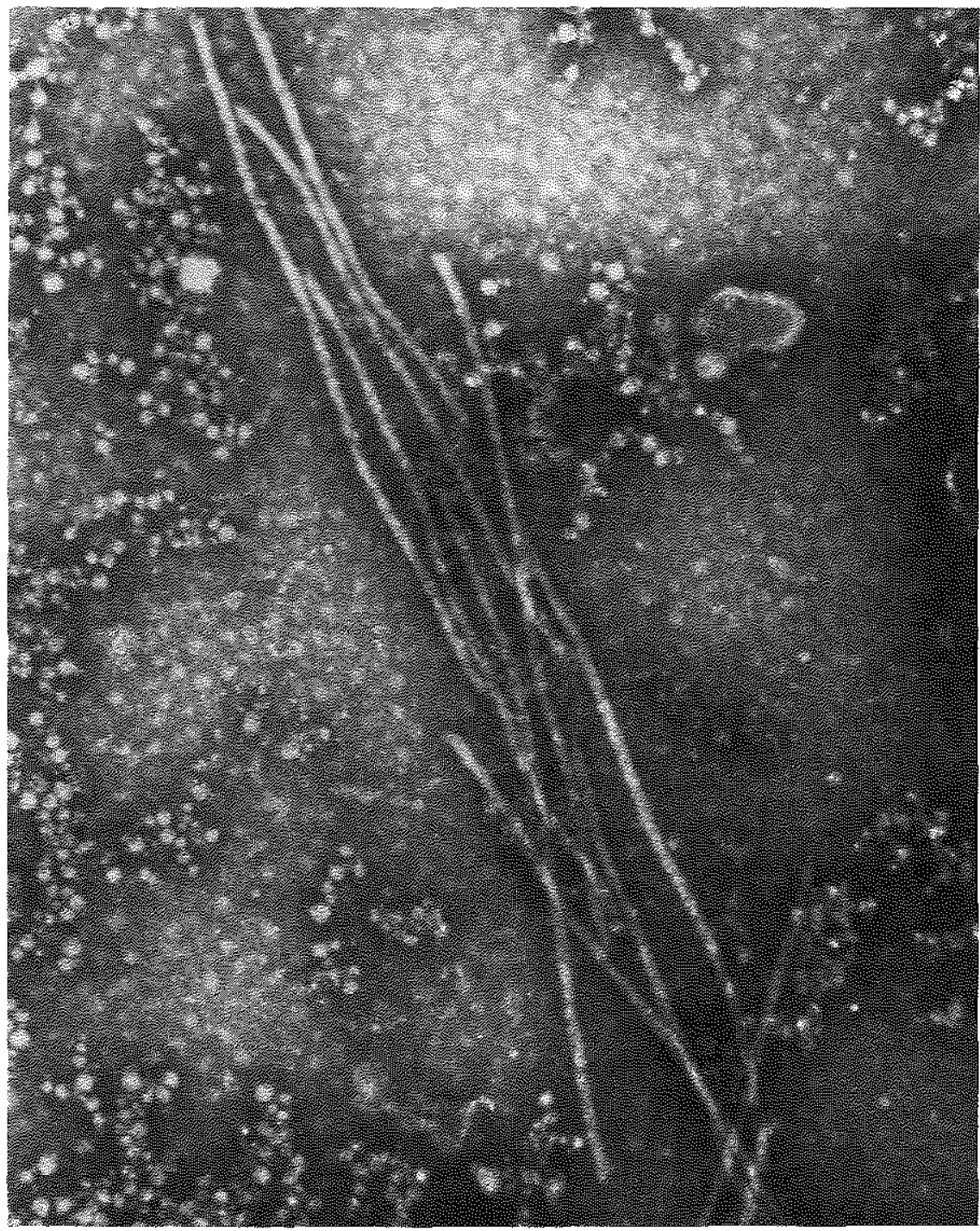

Fug. 1.-Rod-shaped virus particles observed, under the electron microscope, in negatively stained juice, pressed from leaves of sugarcane variety CP31-294 showing typical symptoms of mosaic incited by virus strain A ( $\times 143,000)$.

\section{Trial number 2}

The results from mosaic inoculation studies with a mixture of sugarcane mosaic virus strains $A, B$ and $D$ are summarized in table 2 . The majority of the varieties tested (12 out of 20 ) were either highly resistant or 
SUGARCANE MOSAIC: VIRUS PARTICLES, RELATIVE RESISTANCE 319

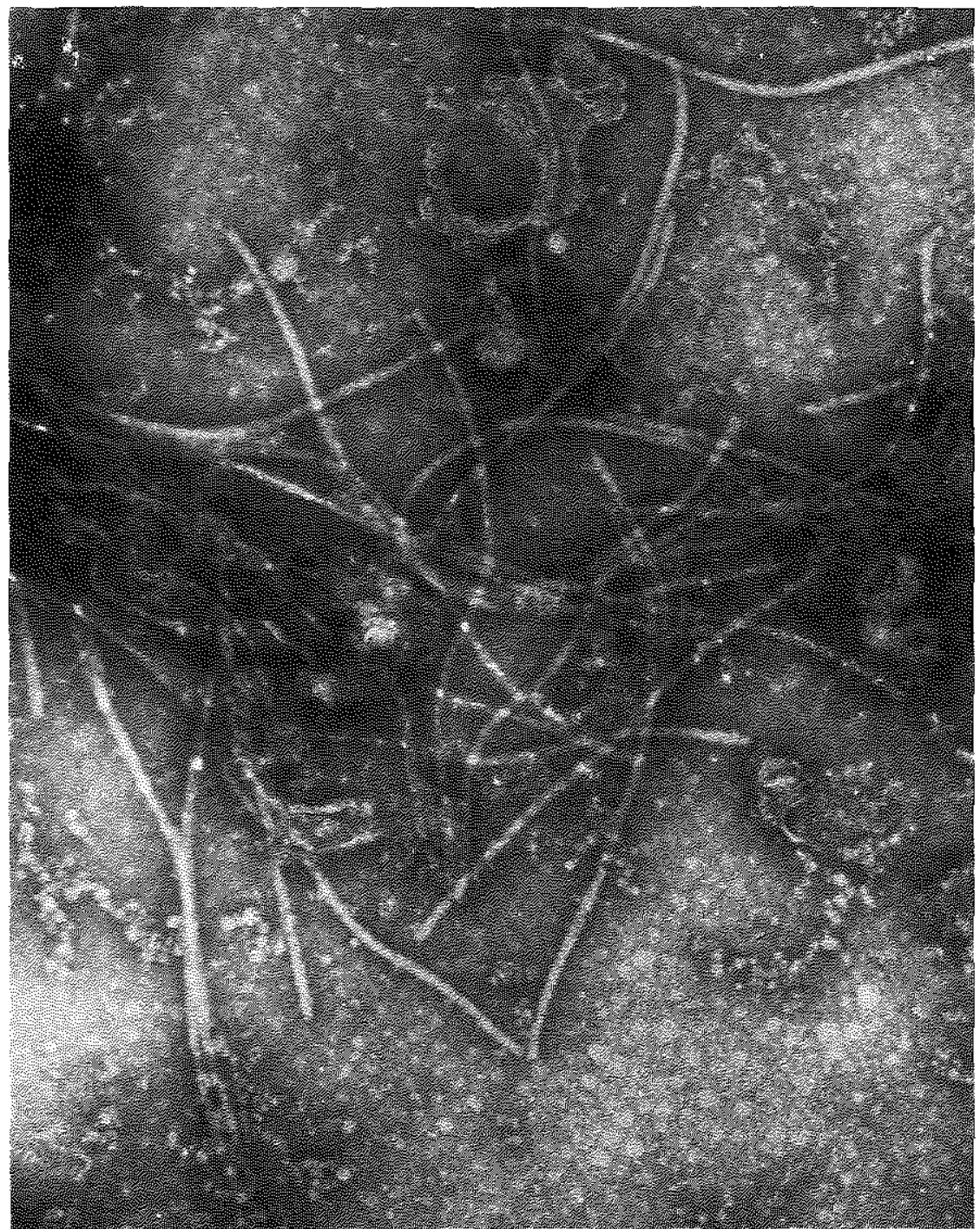

FIG. 2.-Rod-shaped virus particles observed, under the electron microscope, in negatively stained juice, pressed from leaves of sugarcane variety CP31-294 showing typical symptoms of mosaic incited by virus strain $\mathrm{B}(\times 143,000)$.

immune to the agent. The following varieties belong to this group: PR 1140, PR 1141, PR 1249, PR 63-192, PR 63-227, PR 63-488, PR 63-1165, PR 64-352, PR 64-1128, PR 64-1628, PR 64-1791, and PR 65-292. However, varieties PR 1152, PR 64-1548, PR 65-153, and selection Sóller did not differ significantly from B 34-104, but did differ significantly from PR 980 in percentage of plants infected by the mosaic virus. 


\section{Trial number 3}

Table 3 shows the majority of the varieties tested (14 out of 18) were either highly resistant or immune to the mosaic virus. The following varieties belong to this group: PR 1124, PR 1148, PR 61-632, PR 62-469, PR 62-739, PR 63-488, PR 63-525, PR 63-1165, PR 65-625, PR 65-1128, PR 67-245, PR 67-1070, PR 67-3129, and PR 69-2030. However, varieties,

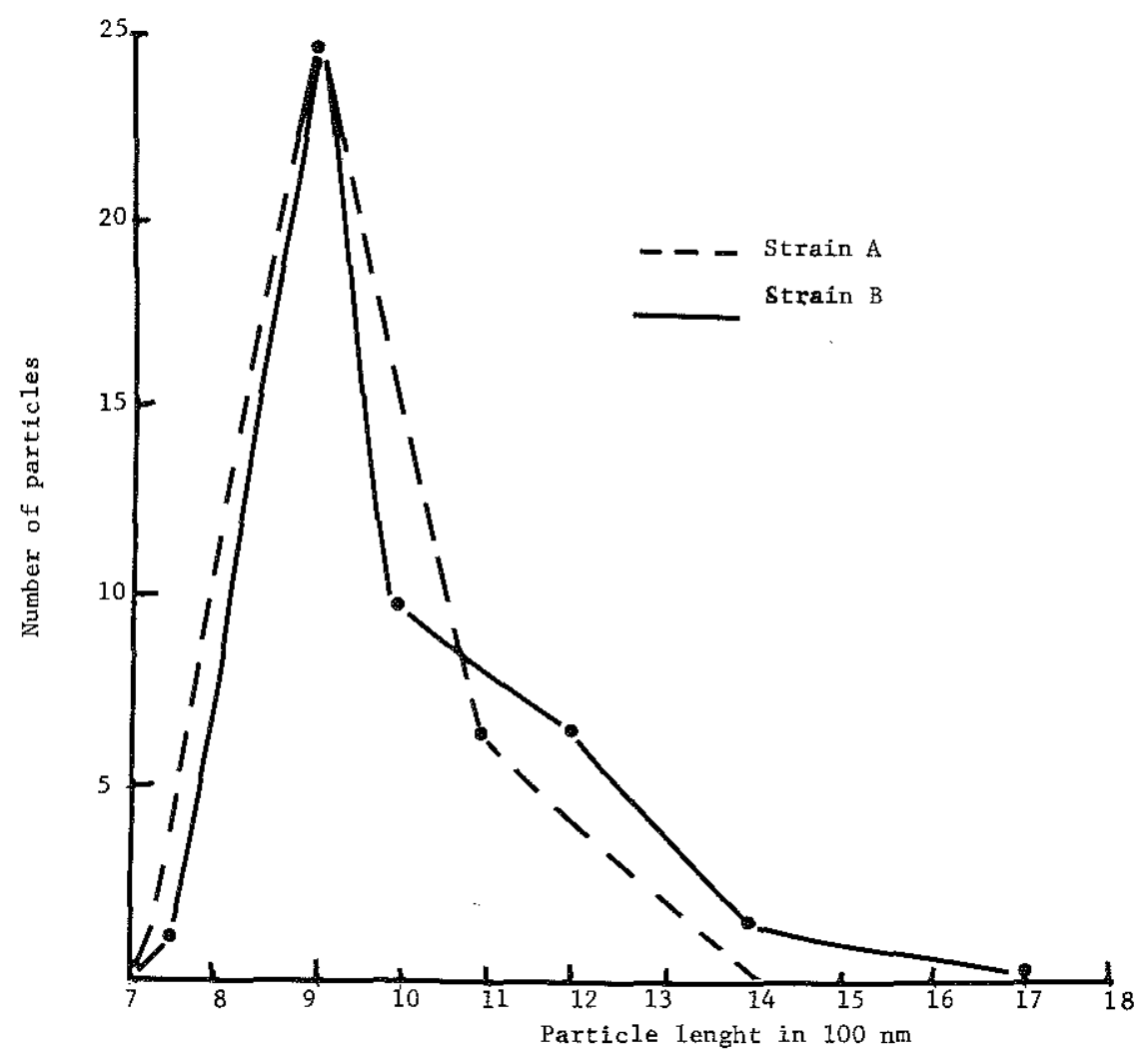

Fig. 3 - Distribution of particle lenghts of sugarcane mosaic virus particles. (Strain $A$ and $B$ ).

FIG. 3.-Distribution of particle lengths of sugarcane mosaic virus particles. (Strain A and $\mathrm{B})$.

PR 64-1548 and PR 65-2538 did not differ significantly from B 34-104, but did differ significantly from PR 980 in percentage of plants infected by the mosaic virus.

\section{DISCUSSION}

The results obtained in this study agree generally with those of Gold and Martin (3), Herold and Weibel (4) and Dos Santos (2), who found 
SUGARCANE MOSAIC: VIRUS PARTIClES, RELATIVE RESISTANCE 321

TABLE 1.-Susceptibility of some promising varieties of sugarcane to a mixture of mosaic virus strain $A, B$ and $D$ in Puerto Rico. (Inoculation trial No. 1 )

\begin{tabular}{|c|c|c|}
\hline Variety & Replications & $\begin{array}{l}\text { Average percentage } \\
\text { of canes showing } \\
\text { mosaic symptoms }\end{array}$ \\
\hline B 34-104 (control) & 4 & $20.64 \mathrm{a}^{\mathrm{l}}$ \\
\hline PR 1140 & 5 & $10.02 \mathrm{a}$ \\
\hline PR 1141 & 4 & $16.66 \mathrm{a}$ \\
\hline PR 1148 & 5 & 0 \\
\hline PR 1152 & 4 & $19.19 \mathrm{a}$ \\
\hline PR 1249 & 4 & $6.04 \mathrm{a}$ \\
\hline PR 61-64 & 4 & 0 \\
\hline PR 61-632 & 4 & 0 \\
\hline PR 61-902 & 4 & 2.08 \\
\hline PR $62-66$ & 4 & 2.50 \\
\hline PR 62-195 & 4 & 0 \\
\hline PR 62-285 & 4 & $17.50 \mathrm{a}$ \\
\hline PR 62-469 & 4 & 1.38 \\
\hline PR $62-626$ & 3 & 0 \\
\hline PR 62-739 & 4 & $5.40 \mathrm{a}$ \\
\hline PR 63-227 & 4 & $6.25 \mathrm{a}$ \\
\hline PR 63-437 & 5 & 3.33 \\
\hline PR 63-525 & 4 & 0 \\
\hline PR 64-15 & 4 & 2.63 \\
\hline PR 64-245 & 5 & $6.88 \mathrm{a}$ \\
\hline PR 64-352 & 5 & $6.66 \mathrm{a}$ \\
\hline PR 64-610 & 5 & 0 \\
\hline PR 64-747 & 5 & 1.81 \\
\hline PR 64-1618 & 4 & 1.78 \\
\hline PR 64-1791 & 4 & 0 \\
\hline PR 64-2002 & 4 & $9.09 \mathrm{a}$ \\
\hline PR 64-2705 & 5 & 0 \\
\hline PR 65-109 & 4 & 0 \\
\hline PR 65-153 & 4 & $9.19 \mathrm{a}$ \\
\hline PR 65-199 & 4 & 1.77 \\
\hline PR 65-339 & 4 & 2.50 \\
\hline PR 65-413 & 4 & $7.44 \mathrm{a}$ \\
\hline PR 65-625 & 4 & $6.71 \mathrm{a}$ \\
\hline PR 65-2638 & 4 & 3.70 \\
\hline $\mathrm{Q} 68$ & 4 & $12.45 \mathrm{a}$ \\
\hline Soller & 4 & $15.86 \mathrm{a}$ \\
\hline Nco 310 & 4 & 2.77 \\
\hline
\end{tabular}

${ }^{1}$ Mean values followed by the same letter do not differ significantly at the $5 \%$ level.

the presence of rod-shaped virus particles in the negatively stained juice pressed from leaves of sugarcane affected by mosaic. The difference in average size of the virus particles between strain $A$ and $B$ was not appreciable, an observation which is in line with the findings of Gold and Martin (3). However, the virus particles were slightly longer and appeared in bunches and more numerous in this case. Addition of a $0.5 \%$ solution of sucrose to the pressed juice from mosaic-affected leaves before staining 
TABLE 3.-Susceptibility of some promising varieties of sugarcane to a mixture of mosaic virus strains $A, B$ and $D$ in Puerto Rico (Inoculation trial No. 3)

\begin{tabular}{|c|c|c|}
\hline Variety & Replications & $\begin{array}{l}\text { Average percentage } \\
\text { of cane showing } \\
\text { mosaic symptoms }\end{array}$ \\
\hline B 34-104 (control No. 1) & 4 & $18.75 \mathrm{a}^{1}$ \\
\hline PR 980 (control No. 2) & 4 & $\begin{array}{ll}0 & \mathbf{b}\end{array}$ \\
\hline PR 1124 & 4 & $0 \quad \mathrm{~b}$ \\
\hline PR 1148 & 4 & $1.56 \mathrm{~b}$ \\
\hline PR 61.632 & 4 & $0 \quad b$ \\
\hline PR $62-469$ & 4 & $2.94 \mathrm{~b}$ \\
\hline PR $62-739$ & 4 & $2.17 \mathrm{~b}$ \\
\hline PR 63-488 & 4 & $1.66 \mathrm{~b}$ \\
\hline PR 63-525 & 4 & $0 \quad b$ \\
\hline PR 63-1165 & 4 & $1.47 \mathrm{~b}$ \\
\hline PR 64-I548 & 4 & $19.18 \mathrm{a}$ \\
\hline PR 65-625 & 4 & $1.25 \mathrm{~b}$ \\
\hline PR 65-1128 & 4 & $0 \quad$ b \\
\hline PR 65-2538 & 4 & $18.54 \mathrm{a}$ \\
\hline PR $67-245$ & 4 & $2.27 \mathrm{~b}$ \\
\hline PR 67-10.70 & 4 & $0 \quad b$ \\
\hline PR 67-3129 & 4 & $0 \quad b$ \\
\hline PR $69-2030$ & 4 & $1.66 \mathrm{~b}$ \\
\hline
\end{tabular}

${ }^{1}$ Mean values followed by the same letter do not differ significantly at the $5 \%$ level.

TABLE 2.-Susceptibility of some promising varieties of sugarcane to a mixture of mosaic virus strain A, B and D in Puerto Rico (Inoculation trial No. 2)

\begin{tabular}{|c|c|c|}
\hline Variety & Replications & $\begin{array}{l}\text { Average percentage } \\
\text { of cane showing } \\
\text { mosaic symptoms }\end{array}$ \\
\hline B 34-104 (control No. 1) & 4 & $18.06 \mathrm{a}^{1}$ \\
\hline PR 980 (control No. 2) & 4 & $\begin{array}{ll}0 & b\end{array}$ \\
\hline PR 1140 & 4 & $\mathrm{~b}$ \\
\hline PR 1141 & 4 & $\begin{array}{ll}0 & b\end{array}$ \\
\hline PR 1152 & 4 & $12.50 \mathrm{a}$ \\
\hline PR 1248 & 4 & $5.55 \mathrm{~b}$ \\
\hline PR 1249 & 4 & $0 \quad b$ \\
\hline PR 62-285 & 4 & $6.78 \mathrm{~b}$ \\
\hline PR 63-192 & 3 & $0 \quad b$ \\
\hline PR 63-227 & 4 & b \\
\hline PR 63-488 & 4 & b \\
\hline PR 63-1165 & 4 & b \\
\hline PR 64-352 & 4 & b \\
\hline PR $64-1128$ & 4 & $0 \quad b$ \\
\hline PR 64-1548 & 4 & $14.27 \mathrm{a}$ \\
\hline PR 64-1628 & 4 & $0 \quad b$ \\
\hline PR 64-1791 & 4 & $\begin{array}{ll}0 & \mathbf{b}\end{array}$ \\
\hline PR 65-153 & 4 & $14.82 \mathrm{a}$ \\
\hline PR 65-292 & 4 & $\begin{array}{ll}0 & \mathbf{b}\end{array}$ \\
\hline Sel. Soller & 4 & $9.86 \mathrm{a}$ \\
\hline
\end{tabular}

${ }^{1}$ Mean values followed by the same letter do not differ significantly at the $5 \%$ level. 
could possibly have contributed to the visibility of the virus particles.

Virus particles of sugarcane mosaic had not been observed under the electron microscope nor had they been associated previously with the disease in Puerto Rico.

The reactions of almost all the varieties to mosaic inoculation were quite consistent except for those of PR 1140, PR 1141 and PR 62-285, which behaved as highly susceptible in the first trial, but highly to moderately resistant in the second. This inconsistency could possibly be explained by the variations in temperature during the inoculation and incubation period (6) as well as by the amount of inoculum used.

Despite the fact that PR 1141, PR 1152, PR 62-285, PR 64-1548, PR 65-153, PR 65-2538, Q 68, and selection Sóller were found potentially capable of taking mosaic, with an average of 10 to $19 \%$ infection from artificial inoculation, none of these varieties showed mosaic symptoms in the field from natural infection. Therefore, from a practical point of view, they are acceptable for field planting in Puerto Rico.

\section{RESUMEN}

De plantas de caña de azúcar de la variedad CP31-294 afectadas con mosaico, se extrajo jugo y se tiñó negativamente. Al examinarlo al microscopio electrónico se observaron partículas bacilares de virus. Las partículas eran de las cepas A y B y medían $720-1,446 \mathrm{~nm} \times 14-15 \mathrm{~nm}$ y $720-1,730 \mathrm{~nm} \times 14-15 \mathrm{~nm}$, respectivamente. Cincuentiuna variedades prometedoras de caña de azúcar se inocularon con una mezcla de las dos cepas en tres experimentos en invernadero durante los últimos 3 años. Las variedades PR 1141, PR 1152, PR 62-285, PR 64-1548, PR 65-153, PR 65-2538, Q 68 y la selección Sóller demostraron ser potencialmente susceptibles, con una infección media de 10 a $19 \%$. Sin embargo, ninguna de estas variedades mostraron síntomas de mosaico cuando se expusieron a la infección natural en cañaverales. Por lo tanto, como no son susceptibles al mosaico, pueden usarse en plantaciones comerciales en Puerto Rico.

\section{LITERATURE CITED}

1. Bruehl, G. W., 1953. Strains of sugarcane mosaic in Puerto Rico, Plant Dis. Rept. ARS, USDA 37: 479-81.

2. Dos Santos, De Fatima, 1962. Estudo ao microcopio electronico do virus do mosaico da cana do açúcar, Estud Agron. (Lisboa) 3, 143-9.

3. Gold, A. H. and Martin, J. P., 1955. Electron microscopy of particles associated with sugarcane mosaic, Phytopathology 45: 694.

4. Herold, F. and Weibel, J., 1963. Electron microscopic demonstration of sugarcane mosaic virus particles in cells of Saccharum officinarum and Zea mays, Phytopathology 53: 469-71.

5. Kitajima, E. W., 1965. A rapid method to detect particles of some spherical plant viruses in fresh preparation, J. Electron Micros. 14(2): 119-21. 
6. Liu, L. J., 1970. Effect of temperatures on symptom expression by sugarcane infected with different strains of mosaic virus, J. Agri. Univ. P.R. 55(1): 128-32.

7. - 1972. Strains of sugarcane mosaic virus in Puerto Rico, J. Agri. Univ. P.R. 56(3): 292-300.

8. Matz, J., 1933. Artificial transmission of sugarcane mosaic, J. Agri. Res. 48: 821-40.

9. Seín, Jr., F., 1930. A new-mechanical method for artificially transmitting sugarcane mosaic, J. Agri. Dep. Agri. P.R., 14: 49-68. 